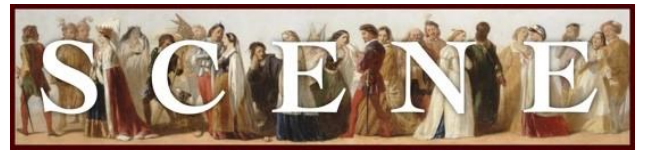

\title{
Murky Macbeth Elicits Standing Ovation at Canada's Stratford Festival
}

by Jim Volz. Written on 2016-08-23. Published in 2017 Issue 1.

For the production: Macbeth (2016, Stratford Festival of Canada, Canada). See production details at the end of the review.

IT WAS A GLORIOUSLY MURKY, SHADOWY, AND DUSKY ELEVENTH-CENTURY SETTING FOR Macbeth, and Canada's Stratford Festival designer Julie Fox's compact, complex set almost stole the show. Fortunately, Director Antoni Cimolino knew how to take full advantage of his cast and entire design team. He commanded an always expected, seldom fulfilled, vibrant, streamlined story of usurpation, guilt, madness, and revenge that provoked a quick standing ovation and audience cheers in the Festival Theater.

It was a clear telling of Duncan's murder, the Macbeths' plotting, Macduff's revenge, and the country's triumph over evil tyranny. But it was not an unblemished production despite the exquisite scene transitions, startling special effects, and chilling sound designs by Composer Steven Page and Designer Thomas Ryder Payne.

From the very beginning of the show, there was a much too relaxed sense of vocal energy and physical dynamism that one would expect from a recently battle-tested, adrenaline-charged Macbeth and Banquo. The three witches (eerily and forcefully rendered by Brigit Wilson, Lanise Antoine Shelley, and Deidre Gillard-Rowlings), did their part to set the two warriors on their prophetic path of doom, but neither Macbeth or Banquo seemed to seize the startling predictions of great fortune with the gravity and/or exhilaration that one might suspect (even when the Thane of Cawdor prophesy was almost instantly fulfilled). Allowing for various directorial or actor interpretations, this was just one example of a number of moments in the show where a key actor's vocal depth, dynamics, tone, or muted force slowed the wild, reckless, and maddening actions of the play. In other moments in the expansive 1800-seat Festival Theater, characters turned upstage or put their faces to the stage floor without increasing volume (often making their lines or speeches indecipherable). 
Still, the individual crafting of scenes was stellar. The slaying of Macduff's family was inspired in its simplicity and horror, as was the ambush of Banquo and the escape of Fleance. The director and actors took their time with the more thoughtful scenes involving the plotting of the Macbeths, the revelation of the slaughter of Banquo's family, and Malcolm's transformation from exiled suspect to ruler (solidly played by Antoine Yared). This set the stage for the rapidfire pace of the march of Birnam Wood on Dunsinane, and the final, well-lit, cut-and-chase denouement of the "invincible" Macbeth.

Ian Lake's Macbeth was solid but often lacking the fire and in-the-moment sense of surprise or awe that communing with the supernatural usually inspires. Krystin Pellerin's Lady Macbeth captured the energy but lacked the nuance that connected Macbeth's initial missive with her intricate and abrupt turn to the dark side. Michael Blake's Macduff was earthy and fierce, and Sara Afful's Lady Macduff was playful and heartbreaking in the wonderfully staged murderous ambush. Scott Wentworth's Banquo was honest and on target and his wandering in and out of the banquet scene was accomplished with clarity and convincing authority.

This was a strong company and a lavish production dedicated to longtime Stratford actor and director, Brian Bedford. Michael Walton's lighting design was sinister and bold, Composer Page and Sound Designer Payne created splendid aural surroundings for the play's most shocking moments, and Fight Director John Stead and Movement Director Heidi Strauss kept the pacing frenetic and fraught with peril when called on. The rousing final confrontation fight between Macbeth (Lake) and Macduff (Blake) was handled with confidence.

Jim Volz is an international arts consultant, author, producer, and professor based in Orange County at California State University, Fullerton. He served as a longtime critic/arts columnist for New York's Back Stage and founding editor of the Shakespeare Theatre Association's international magazine, Quarto. He has produced over 100 professional productions, consulted for over 100 arts institutions and published more than 100 articles on management, arts criticism, Shakespeare, and theatre in American Theatre, Oxford University Press's Theatre Research International, Hollywood's Drama-Logue and myriad other articles for national and international publications. He is a Ph.D. graduate from the University of Colorado,Boulder.jvolz@fullerton.edu 


\section{Production Details}

\section{General}

$\begin{array}{ll}\text { Title } & \text { Macbeth } \\ \text { Year } & 2016 \\ \text { Theater Company } & \text { Stratford Festival of Canada } \\ \text { Theaters } & \text { Festival Theatre (Canada) } \\ \text { Start Date } & 2016-05-30 \\ \text { End Date } & 2016-11-05\end{array}$

\section{Cast}

\begin{tabular}{|c|c|}
\hline МАСВЕТН & IAN LAKE \\
\hline LADY MACBETH & KRYSTIN PELLERIN \\
\hline KING DUNCAN & JOSEPH ZIEGLER \\
\hline MALCOLM & ANTOINE YARED \\
\hline DONALBAIN & EMILIO VIEIRA \\
\hline BANQUO & SCOTT WENTWORTH \\
\hline MACDUFF & MICHAEL BLAKE \\
\hline LADY MACDUFF & SARAH AFFUL \\
\hline LENNOX & JAMIE MAC \\
\hline Ross & DAVID COLLINS \\
\hline MENTETH & SANJAY TALWAR \\
\hline ANGUS & TIM CAMPBELL \\
\hline CATHNESS & ROBERT KING \\
\hline FLEANCE & DECLAN COOPER \\
\hline OLD SIWARD & PETER HutT \\
\hline YOUNG SIWARD & RODRIGO BEILFUSS \\
\hline SECOND WITCH & DEIDRE GILLARD-ROWLINGS \\
\hline THIRD WITCH & LENISE ANTOINE SHELLEY \\
\hline FIRST WiTCH & BRIGIT WILSON \\
\hline SEYTON & E.B. SмITH \\
\hline UNDERSTUDY & TRISH LINDSTROM \\
\hline ENGLISH DOCTOR & JOHN KIRKPATRICK \\
\hline PORTER & CyRUS LANE \\
\hline OLD MAN & BRIAN TREE \\
\hline GENTLEWOMAN & IJEOMA EMESOWUM \\
\hline SECOND MURDERER & Peter Hutt \\
\hline FIRST MURDERER & ROBERT KING \\
\hline
\end{tabular}




$\begin{array}{ll}\text { Apparition } & \text { Sophie NeUdorf } \\ \text { LAdy Macbeth's Attendant } & \text { Jessica B. Hill } \\ \text { Messenger } & \text { Alexei DeLuCA } \\ \text { Understudy } & \text { Petrina Bromley } \\ \text { Young Macduff } & \text { Oliver NeUdorf }\end{array}$

\section{Creatives}

$\begin{array}{ll}\text { Director } & \text { Antoni Cimolino } \\ \text { Assistant Director } & \text { James Wallis } \\ \text { Assistant Costume Designer } & \text { Julia Holbert } \\ \text { Assistant Set Designer } & \text { T. Erin Gruber } \\ \text { Assistant Lighting Designer } & \text { Bryan Kenney } \\ \text { Lighting Designer } & \text { MiChael Walton } \\ \text { Sound Designer } & \text { Thomas Ryder Payne } \\ \text { Composer } & \text { Steven Page } \\ \text { Associate Fight Director } & \text { Geoff Scovell } \\ \text { Fight Director } & \text { John Stead } \\ \text { Stage Manager } & \text { Anne Murphy } \\ \text { Assistant Stage Manager } & \text { Julie Miles } \\ \text { Assistant Stage Manager } & \text { Corinne Richards } \\ \text { Production Stage Manager } & \text { Margaret Palmer } \\ \text { Production Stage Manager } & \text { Cynthia Toushan } \\ \text { Apprentice Stage Manager } & \text { Katherine Dermott } \\ \text { Designer } & \text { Julie Fox } \\ \text { Movement Director } & \text { Heidi Strauss }\end{array}$

